PRÁVNE ROZPRAVY ON-SCREEN III. - Sekcia verejného práva

online vedecká konferencia - 7. máj 2021

\title{
THE LEgal REgulation OF AI IN THE EU: THE POLICY MEASURES AND THE FUTURE PERSPECTIVE
}

Yevhen Shcherbyna ${ }^{1}$

https://doi.org/10.24040/pros.07.05.2021.svp.259-271

\begin{abstract}
The paper is devoted to the topic of the issues surrounding the existing policy measures regarding artificial intelligence in the EU. This technology brings new opportunities and can be quite useful in various spheres of social life but at the same time, it raises ethical concerns and issues in respect of the potential intrusion of the technology into peoples' private lives. The paper will include the analysis of the approaches towards the legal definition of AI, its types, pros, cons and consequences of the incorporation of the technology in our social relations. Also, the future perspective of the regulatory framework on AI will be analyzed.
\end{abstract}

\section{Key words}

AI and Law, Artificial Intelligence Regulation, The Legal Framework for AI, The EU perspective on the regulation of AI, Artificial Intelligence Act.

\section{Introduction}

Artificial intelligence is a concept that draws more and more attention during the last couple of years. As a technology, it represents a tool that is capable of assisting human activity in many different fields: from the games and the entertainment sector to the solution of complex mathematical equations and the creation of neural networks that can help humanity cure diseases . That being said, this technology that is mostly referred to as rather beneficial and the one that can facilitate human life in many aspects, at the same time, raises some concerns regarding the possible intervention of it into people's privacy. To put it simply, the development of artificial intelligence raises some ethical worries, concerns that should be addressed.

This paper constitutes an attempt to analyze the policies and a regulatory framework that have been developed in the EU for the last couple of years and whose aim is to gradually implement the technology of artificial intelligence into the existing bulk of legislation that regulates social relations arising from the interconnection of human privacy and data protection on the one hand and new technologies on the other hand.

1 Ph.D. student, Law School, Mykolas Romeris University, Vilnius, Lithuania; Contact: yeshcherbyna1@stud.mruni.eu; ORCID 0000-0002-5400-6403. 


\section{PRÁVNE ROZPRAVY ON-SCREEN III. - Sekcia verejného práva}

online vedecká konferencia - 7. máj 2021

It is likely that the EU's current vectors of development in the sphere of AI legislation will have a significant impact on the other global players in this domain.

\section{The notion of artificial intelligence. Strong and weak AI}

Before we proceed with the current legal status of artificial intelligence in the European Union, to have a better understanding of what we are dealing with, it is important to outline the concept of an AI itself; its defining characteristics and the types of technology at hand.

Currently, there is no universally accepted definition of artificial intelligence across the scholarly community as the debates regarding the spectre of the essential features of this technology that must be included in such a notion are still ongoing. ${ }^{2}$ Among the plethora of the already proposed definitions, these range from the purely tech-oriented to the ones that aim at being usable for the legal domain.

One of the first attempts to define the concept of artificial intelligence traces back to the year 1955 where John McCarthy, Marvin L. Minsky, Nathaniel Rochester and Claude E. Shannon first presented their paper called 'A Proposal for the Dartmouth Summer Research Project on Artificial Intelligence' where the authors deduced the following: '...the artificial intelligence problem is taken to be that of making a machine behave in ways that would be called intelligent if a human were so behaving'. ${ }^{3}$ This is of somewhat vague concept places the human factor at the decisive element - a machine would be treated as to be intelligent if this machine acts in a manner as replicating the human patterns of behaviour.

To find the definition of the concept of artificial intelligence that would be better suitable for the subsequent legal application, we can refer to a more modern analysis - the one that was conducted by the Independent High-Level Expert Group on Artificial Intelligence - the body that was specifically set up by the European Commission with the purpose to research the peculiarities of functioning and the potential hurdles of the AI-driven technologies for the upcoming regulatory framework in the relevant field of social relations. One of their reports, that subsequently formed part of the Commission's Communication on the topic of Artificial Intelligence, provides for the following definition of the technology at hand: 'Artificial

\footnotetext{
${ }^{2}$ SCHUETT, J.: A Legal Definition of AI. In: ArXiv: 1909.01095v1 [online]. Frankfurt: 2019 [cit. 2021-05-02], p. 3. Available at: https://papers.ssrn.com/sol3/papers.cfm?abstract_id=3453632.

${ }^{3}$ GIUFFRIDA, I. - LEDERER, F. - VERMEYS, N.: A Legal Perspective on the Trials and Tribunals of AI: How Artificial Intelligence, the Internet of Things, Smart Contracts, and Other Technologies Will Affect the Law. In: Case Western Reserve Law Review, 2018, Vol. 68, Iss. 3. ISSN 0008-7262, p. 752.
} 


\section{PRÁVNE ROZPRAVY ON-SCREEN III. - Sekcia verejného práva}

online vedecká konferencia - 7. máj 2021

Intelligence (AI) refers to systems that display intelligent behaviour by analysing their environment and taking actions - with some degree of autonomy - to achieve specific goals'. ${ }^{4}$

Together with the provided definition, the Communication gives us further clarifications on the possible types of the AI-driven solutions stating that these can be presented in the following forms: 'AI-based systems can be purely software-based, acting in the virtual world, (e.g. voice assistants, search engines, speech and face recognition systems) or AI can be embedded in hardware devices (e.g. advanced robots, autonomous cars, drones or Internet of Things applications)". 5

The definition of the concept and the further clarification on the possible forms of the AI-driven applications provide us with the possibility to deduce the key distinctive features of the notion of the technology at hand:

- This is a set of algorithms, procedures or scripts;

- that manifests in a form of a system;

- and enables such a system to autonomously perceive and interact with the surrounding environment;

- to take certain actions and derive conclusions from such actions and interaction with the environment;

- learn from the consequences of such an interaction;

- in a way that simulates human-like behavioural patterns.

A certain degree of autonomy and an ability to learn in a human-like fashion are the distinctive features that separate AI-driven applications from the bulk of the various other systems that are constructed in the form of algorithms, scripts, etc. but, unlike AI, are preprogrammed and limited in their functionality and the learning potential.

The scope of the technology and the types of AI

Again, as with the definition of artificial intelligence itself, there are ongoing debates as to what fields of application AI encompasses. Certain scholars and practitioners including the developers of AI-driven solutions like the founders of Ross Intelligence platform ${ }^{6}-\mathrm{a}_{\text {legal }}$

\footnotetext{
${ }^{4}$ BAUER, W. et al: A Definition of AI: Main Capabilities and Scientific Disciplines. In: Report/study by the HighLevel Expert Group on Artificial Intelligence [online]. Brussels: European Commission, 2019 [cit. 2021-05-03], p. 1. Available at: https://digital-strategy.ec.europa.eu/en/library/definition-artificial-intelligence-maincapabilities-and-scientific-disciplines.

${ }^{5}$ Ibid.

${ }^{6}$ ROSS Intelligence, an AI-driven legal-research software. More at: https://www.rossintelligence.com/about-us.
} 


\section{PRÁVNE ROZPRAVY ON-SCREEN III. - Sekcia verejného práva}

online vedecká konferencia - 7. máj 2021

research software aimed at speeding up lawyers' document research process derive four main types of technologies that fall within the scope of artificial intelligence, namely: machine learning, speech recognition, natural language processing, and image recognition. ${ }^{7}$ This approach is rather narrow as it leaves aside such AI-driven applications as AI-driven tools for computer games, AI embedded into the IoT devices etc.

On the contrary, the European Parliament that together with the Commission and the Council conduct the preparatory works for the upcoming EU-level regulatory framework aimed at covering the AI-related issues seems to take the wider approach indicating in its publications devoted to the issues of artificial intelligence that such a concept includes a wide variety of applications ranging from smartphone digital assistants and machine translation tools to the autonomous cars, smart farming applications and AI-driven robots. ${ }^{8}$ Such an approach to interpreting artificial intelligence rather widely can be an indicator of a general trend in the EU's policy regarding the regulatory approach when it comes to addressing the challenges that the new technologies pose before the regulatory authorities. The idea here is to cover almost all possible applications that AI-driven solutions can intervene with to ensure that the rights and freedoms of EU citizens remain protected.

This is a common issue when it comes to the creation of the legal framework in respect of the modern disruptive technologies: the legislator needs to maintain the fragile balance between the promotion of the further development of technology to remain competitive on the global market while at the same time it is necessary to establish the safeguard mechanisms that would allow for the prevention of the excessive intrusion of technology into the human lives. Artificial intelligence qualifies for such a concept of a disruptive technology that requires high attention from policymakers.

\section{$\underline{\text { Strong and weak AI }}$}

When it comes to the categorization of the different AI-driven applications into multiple groups depending on their function-set, purpose, level of automation, etc., there are various approaches to that which, again, cannot boast a certain degree of uniformity in the scholarly

\footnotetext{
${ }^{7}$ GIUFFRIDA, I. - LEDERER, F. - VERMEYS, N.: A Legal Perspective on the Trials and Tribunals of AI: How Artificial Intelligence, the Internet of Things, Smart Contracts, and Other Technologies Will Affect the Law. In: Case Western Reserve Law Review, 2018, Vol. 68, Iss. 3. ISSN 0008-7262, p. 753.

${ }^{8}$ What is Artificial Intelligence and how it is Used? [online]. Brussels: European Parliament, 2020 [cit. 2021-0503], Available at: https://www.europarl.europa.eu/news/en/headlines/society/20200827STO85804/what-isartificial-intelligence-and-how-is-it-used.
} 


\section{PRÁVNE ROZPRAVY ON-SCREEN III. - Sekcia verejného práva}

online vedecká konferencia - 7. máj 2021

society. Thus, for this paper, I will concentrate on the division that I regard as to be one of the most important from the standpoint of the policymaking - the grouping based on the degree of autonomy and 'freedom' that such AI-driven solutions are equipped with. When it comes to such freedom of actions, it is possible to divide the AI solutions into the so-called: 'weak' and 'strong' AI. ${ }^{9}$ The idea behind such a division is the following: the AI-driven solutions that are characterized as the 'strong' ones are theoretically capable of 'demonstrating cognitive abilities' similar to the ones of a human and in their education reach beyond what was initially pre-programmed by the developers of such an AI machine. On the contrary, the so-called 'weak' AI-driven applications typically cannot go farther from what was initially designed as their feature-set by their constructors. ${ }^{10}$

A good illustration of technological applications that can be implemented in both the weak AI and strong AI forms is a chat-bot. These are the AI-driven solutions that facilitate human activity in various ways. Say, we have a situation where a person needs to find transport tickets and plan the most convenient itineraries for an upcoming vacation. Such a person may refer to one of the existing plethoras of chat-bots that can help to automate that process by managing the person's inputs e.g. dates of the trip, budget, etc. and providing him/her with the possible directions and ticket options. ${ }^{11}$ These types of chat-bots are deemed to belong to the group of the 'weak AI' tools as they are pre-programmed with strict functionality in mind - to assist people to find the best possible itineraries and public transport options for their trips, in our case. One cannot ask such a chat-bot any random question on, say, politics and expect an answer to that question.

On the other hand, chatbots can be created specifically to be able to hold a conversation on various topics and to learn from the communication with real people. These types of chatbots can be referred to as the category of the 'strong-AI' as there are no pre-designed outputs for any types of questions that people may pose. An example of such a chatbot may be the creation of Microsoft - the bot for Twitter named Tay. It was designed with the idea to engage in communication with US-based Twitter users and learn based on the outcomes of such a communication. The attempt was unsuccessful as the bot's development took an unpredictable

\footnotetext{
${ }^{9}$ MAJID AL-RIFAIE, M. - BISHOP, M.: Weak vs. Strong Computational Creativity. In: Conference: AISB 2012: Computing and Philosophy [online]. Conference Paper, 2012 [cit.2021-05-04], p. 3. Available at: https://www.researchgate.net/publication/262223177_Weak_vs_Strong_Computational_Creativity. ${ }^{10}$ Ibid.

${ }^{11}$ An example of a chat-bot with such a functionality: Mindsay bots developed for these use-cases. More at: https://www.mindsay.com/chatbot/travel.
} 


\section{PRÁVNE ROZPRAVY ON-SCREEN III. - Sekcia verejného práva}

online vedecká konferencia - 7. máj 2021

and undesired direction when Tay started to post tweets that have been recognized by the audience of the platform as those that contain racism. Microsoft eventually shut the chatbot down after only 16 hours of operation. ${ }^{12}$

The abovementioned example of a chatbot that has almost no boundaries as regards the possible directions of its 'evolution' is not only an illustration of an application that belongs to one of the two large groups of AI-driven solutions - the so-called 'strong AI' but also serves as an important warning that such a disruptive technology, if approached without the due caution, may cause some significant negative impact on humanity in the form of the intrusion into their daily lives and the possible violation of their rights and freedoms. This situation is also an indication that artificial intelligence as a technology will not be left uncontrolled and without any regulatory framework. Indeed, such a framework is already under development in various jurisdictions including the EU. During the following chapters, we will have a closer look at what are the goals of the European Union when it comes to the creation of a legal framework for AI systems.

\section{The EU's policy on AI: current state and aims}

As the technology that involves AI-driven solutions matures and the number of issues revolving around AI multiply year by year, countries around the world start to think about the possibility to develop and present the regulatory policy that would introduce the legal boundaries within which the AI-systems can operate. In other words, many jurisdictions are now interested in creating the coherent and clear 'rules of the game' for developers of AI-driven applications, their distributors and other participating actors - all to ensure that the consumers' fundamental rights and freedoms remain protected.

As for the European Union, up to this moment (at the Union level), there is no primary legislation in force that would comprehensively regulate social relations that involve an AIbased element. ${ }^{13}$ The primary legislation in the form of a directive or a regulation, though, is not the only source that can reveal the policy vectors in respect of the future of the artificial

\footnotetext{
${ }^{12}$ HUNT, E.: Tay, Microsoft's AI chatbot, gets a crash course in racism from Twitter. In: The Guardian 2016 [online]. [cit. 2021-05-05], Available at: https://www.theguardian.com/technology/2016/mar/24/tay-microsoftsai-chatbot-gets-a-crash-course-in-racism-from-twitter.

${ }^{13}$ At the time the paper was in preparation (April-May 2021), the European Commission published a Proposal for a Regulation that would address the issues surrounding the use of AI-driven solutions. The so-called 'Artificial Intelligence Act' is ought to become as important a piece of legislation in the relevant field as the GDPR in the sphere of data protection. The key points of this Regulation will also be covered in the paper.
} 


\section{PRÁVNE ROZPRAVY ON-SCREEN III. - Sekcia verejného práva}

online vedecká konferencia - 7. máj 2021

intelligence technology within the Union. Currently, there are multiple sources that belong to the category of 'soft law' that can shed some light on the regulatory trends regarding AI. Among the known samples of soft-law in the area of AI are the European Parliament study devoted to 'The ethics of artificial intelligence: Issues and initiatives'; the European Commission's 'Report on the safety and liability implications of Artificial Intelligence, the Internet of Things and robotics'; the European Commission's 'Liability for Artificial Intelligence and other emerging digital technologies' - a report prepared by the Expert Group on Liability and New Technologies Formation; and the European Commission's 'White Paper on Artificial Intelligence' - a landmark document establishing a 'European approach to excellence and trust'.

The main pillars of the upcoming regulatory framework in respect of artificial intelligence are set in this White Paper. It is envisioned that the two ecosystems working in conjunction will be established to set the boundaries for the participants of the social relations that involve an AI element - the 'ecosystem of excellence' and the 'ecosystem of trust'. ${ }^{14}$ The ecosystem of excellence provides for the promotion of the cooperation between the EU Member States in the sphere of supervision over the process of development and deployment of the AIdriven solutions and exchange of the data regarding the regulatory initiatives in the EU MS in respect of the AI technology to level the playing field on the market of the mentioned technological applications and ensure the congruence of the regulatory tools that are to be adopted in respect of the AI-systems. In addition to that, the consolidation of the EU MS' efforts in the field of investment programmes to boost the effectiveness of the research and development initiatives is also set as the key priority within the framework of the ecosystem of excellence. $^{15}$

In my point of view, the core idea behind the set of efforts described under the ecosystem of excellence is the creation of the cooperative environment within the Union that would incentivize the exchange of ideas and solutions in the sphere of artificial intelligence and would ensure the leading role of the EU in the global AI race. In other words, the global competitiveness of the EU and unity is key when it comes to the ecosystem of excellence.

\footnotetext{
${ }^{14}$ White Paper on Artificial Intelligence - a European approach on excellence and trust. In: White Paper [online]. Brussels: European Commission, 2020 [cit.2021-05-06]. Available at: https://ec.europa.eu/info/sites/default/files/commission-white-paper-artificial-intelligence-feb2020_en.pdf.

${ }^{15}$ VAN EECKE, P. et all: AI Outlook: Europe initiates AI regulation introducing the principle of trustworthy AI. In: Technology's Legal Edge. A global technology sector blog, DLA Piper [online]. 2020 [cit.2021-05-08], Available at: https://www.technologyslegaledge.com/2020/03/ai-outlook-europe-initiates-ai-regulationintroducing-the-principle-of-trustworthy-ai/\#page $=1$.
} 


\section{PRÁVNE ROZPRAVY ON-SCREEN III. - Sekcia verejného práva}

online vedecká konferencia - 7. máj 2021

That being said, artificial intelligence as a technology characterises a high degree of disruptiveness ${ }^{16}$ and thus the creation of a regulatory regime that concentrates solely on the stimulation of the uncontrolled progression and scaling would be at least naïve.

Since the development of the AI-driven applications, when approached carelessly, may pose a threat to human rights and freedoms (especially in the domain of data protection), the EU policymakers decide to, simultaneously with the creation of the ecosystem of excellence, establish the ecosystem of trust. This ecosystem can be regarded as the flip side of the coin the set of mechanisms that, while not hampering the efficient development of the AI-driven solutions, ensure the preservation of an already established set of standards in the domain of the rights and freedoms of the EU citizens - the potential consumers of the mentioned new technologies.

The core elements of the ecosystem of trust are the following: the emphasis on the applicability of the neighbouring legislation on the social relations that involve an AI element (such as the data protection, consumer protection or product safety legislation, etc.); the importance of the adaptation of the existing neighbouring legislation to the new reality where AI plays a significant role in many spheres of social life (this is due to the potential ambiguity and opacity of the artificial intelligence as a technology where its influence on the people's lives may manifest itself in an indirect form), etc. ${ }^{17}$ And the most significant novel that subsequently served as a core pillar of the Commission's Proposal for a Regulation dealing with the issues of artificial intelligence (the Artificial Intelligence Act), is the idea of the so-called 'risk-based approach' towards the AI-driven applications - the model that I will be going to describe in more detail in the subsequent chapter of the current paper and that presumes the attribution of any new AI-system to one of the prescribed groups of AI-driven solutions based on its potential risk. ${ }^{18}$

\footnotetext{
${ }^{16}$ The idea behind the so-called 'disruptive technology' or 'disruptive innovation' refers to the emergence of a technology that can significantly alter a given industry's patterns of competition. For more details, see CHRISTENSEN, C.M. - RAYNOR, M.E. - McDONALD, R.: What is Disruptive Innovation? In: Harvard Business Review [online]. Brighton MA, 2015 [cit.2021-05-08], Available at: https://hbr.org/2015/12/what-isdisruptive-innovation.

${ }^{17}$ VAN EECKE, P. et all: AI Outlook: Europe initiates AI regulation introducing the principle of trustworthy AI. In: Technology's Legal Edge. A global technology sector blog, DLA Piper [online]. 2020 [cit.2021-05-08], Available at: https://www.technologyslegaledge.com/2020/03/ai-outlook-europe-initiates-ai-regulationintroducing-the-principle-of-trustworthy-ai/\#page=1.

${ }^{18}$ White Paper on Artificial Intelligence - a European approach on excellence and trust. In: White Paper [online]. Brussels: European Commission, 2020 [cit.2021-05-06], p.16 Available at: https://ec.europa.eu/info/sites/default/files/commission-white-paper-artificial-intelligence-feb2020_en.pdf.
} 


\section{PRÁVNE ROZPRAVY ON-SCREEN III. - Sekcia verejného práva}

online vedecká konferencia - 7. máj 2021

The mentioned novelties constitute the foundation of the future primary legislation that will specifically aim at artificial intelligence technology. That being said, the current overview would be incomplete without mentioning the existing neighbouring legislation that has an indirect influence on the social relations that involve AI as their element. Among the most notable pieces of legislation in the neighbouring domains that under certain circumstances also impact the social relations that involve an AI-element are the GDPR that comes into play when the AI-driven solutions operate with the personal data of the EU citizens; the Regulation (EU) 2018/1807 that becomes relevant in the cases where the operation of the AI-driven applications is tied with the use of the non-personal data; the Directive 2001/95/EC that regulates the social relations revolving around the issues of the safety of non-food products will also be applicable in a case such a product contain an AI-driven mechanism as its part, etc. ${ }^{19}$ This is just a small portion of neighbouring legislation that may influence the social relations that involve an AI element and serves as an illustration of how interconnected the different spheres of social relations may be and what requirements to the coherence of the EU's legislation these issues pose.

\section{The upcoming Regulation on AI ('the Artificial Intelligence Act')}

Now that we illustrated the existing soft law mechanisms in respect of AI, as well as the examples of the neighbouring legislation in this domain, it is time to break down the recently published Commission's Proposal on the new so-called Artificial Intelligence Act $^{20}$ that will come in the form of a Regulation and will likely have a similar impact on the relevant social relations as the GDPR has on the issues of data protection. Since we are limited in volume, it is necessary to deduce the most important principles and rules that shape this upcoming piece of legislation and that will impact various actors across the Union.

\footnotetext{
${ }^{19}$ The Directive 'On General Product Safety' is relatively old and soon will be substituted by the new piece of legislation that would, among other things, better address the issues regarding the use of AI-driven technologies in consumer products. For more detail, see the Commission's Communication presenting the 'Commission Work Programme 2020' where it is stated that the revised version of the legislation on general product safety is to be presented in the form of a Regulation. Also, the 'Opinion of the Sub-group on Artificial Intelligence, Connected Products and Other New Challenges in Product Safety to the Consumer Safety Network' issued by the Commission, where AI is named among the main innovations that challenge the existing concept of 'safety' and thus require an update to the existing legislation in this sphere.

${ }^{20}$ The Commission's Proposal for a Regulation 2021/0106 (COD) of the European Parliament and of the Council Laying Down Harmonized Rules on Artificial Intelligence and Amending Certain Union Legislative Acts.
} 


\section{PRÁVNE ROZPRAVY ON-SCREEN III. - Sekcia verejného práva}

online vedecká konferencia - 7. máj 2021

According to the Proposal, it will regulate the social relations occurring at every stage of the life-cycle of an AI-driven solution starting from its development (through certain ex-ante obligations e.g. prohibition of certain practices; requirement to inform the regulatory bodies, etc.) and deployment on the Union's market through its operation stages up to the ending of the life-period of such systems. ${ }^{21}$ The envisioned Regulation will have an extraterritorial effect and will apply to the providers, operators, importers, distributors, users of the AI systems, etc. with an exemption granted to the purely private use-cases; entities developing/ supplying/ supporting, etc. AI for military purposes; as well as international organizations, third countrypublic authorities where they use AI systems within the framework of international agreements. $^{22}$

The Regulation Proposal takes a relatively wide stance of the concept of AI operating with the notion of an 'AI system' - a broad definition that encompasses '...software that [by relying on] certain techniques... can... generate outputs... [that] influence the environments they [AI systems] interact with. ${ }^{23}$ As we can see from such a notion, it is very much in line with the concept and its structural elements that have been outlined in the first chapter of the current paper.

The legislator, when drafting the body of the Proposal, showed consistency and provided for the following core ideas that have previously already been elaborated in the Union's soft law: 1) the introduction of the multi-level pyramidal system of the AI-driven solutions with different requirements for each of the groups; 2) the introduction of the liability regime for violators of the rules which prescribes for certain penalties depending on the severity of an infringement and 3) the implementation of certain principles of supervision over the functionality of the AI systems - a practical application of the findings that have been previously formed as the so-called 'ethical' concerns and requirements ${ }^{24}$ in respect of the AIdriven solutions such as human oversight; record keeping; mitigation and control measures; etc. ${ }^{25}$ The pyramidal grouping of AI systems looks the following: a practical implementation of

\footnotetext{
${ }^{21}$ Art. $1 ; 9 ; 12$, etc. of the Regulation Proposal.

22 Ibid, art. 2.

${ }^{23}$ Ibid, para. (1) art. 3.

${ }^{24}$ Ethics guidelines for trustworthy AI [online]. Brussels: European Commission. High-Level Expert Group on Artificial Intelligence, 2020 [cit.2021-05-10], Available at: https://digital-strategy.ec.europa.eu/en/library/ethicsguidelines-trustworthy-ai.

${ }^{25}$ The Commission's Proposal for a Regulation 2021/0106 (COD) of the European Parliament and of the Council Laying Down Harmonized Rules on Artificial Intelligence and Amending Certain Union Legislative Acts, chapter 2.
} 


\section{PRÁVNE ROZPRAVY ON-SCREEN III. - Sekcia verejného práva}

online vedecká konferencia - 7. máj 2021

a so-called 'risk-based approach' with segmentation into four elements depending on the 'risk' that these AI solutions represent for the EU's market and its consumers - from the applications with 'minimal risk' at the bottom of the 'pyramid' that require minimal intervention on the side of the regulator through the applications of a 'limited risk' with certain transparency obligations for the operators of such systems to the applications of a 'high risk' - those require stricter approach in respect of their operators' obligations. Finally, on the top of the 'pyramid' rests category of AI systems that are so dangerous for the freedoms of the EU's consumers that pose 'unacceptable risk' and are subject to a prohibition on their deployment onto the market (e.g. the certain types of real-time remote biometric identification systems). ${ }^{26}$ As for the 'high-risk' systems, the specific groups of these applications are listed exhaustively in an Annex to the Regulation with the power given to the Commission to periodically review and update this list. ${ }^{27}$

The supervision over the compliance with the introduced legislative regime is to be conducted in cooperation between the national supervisory authorities (responsible for their field of control) and the specifically created supranational body - the European Artificial Intelligence Board. Depending on the type and severity of an infringement, such supervisory authorities may lay down penalties up to EUR $30 \mathrm{~m}$ or $6 \%$ of the total worldwide annual turnover of the preceding financial year. ${ }^{28}$

\section{Conclusion}

The purpose of this analysis was to outline the foundations of the concept of artificial intelligence, its complexity and its important role in our daily lives. As we could see on an example of the European Union, big players on the global market of AI-driven solutions take this technology seriously and have already initiated the debates and preparations for the introduction of regulatory frameworks that are supposed to structure the rules of the game for participating actors on the side of businesses on the one hand while ensuring the preservation and guarantees for the fundamental rights and freedoms of the consumers of such a technology.

The EU is currently in its final stages of the development and deployment of the legislative mechanism in the form of a Regulation that will ensure its leading role in the global AI race through the implementation of the balanced legal framework that consists of the two

\footnotetext{
${ }^{26}$ Ibid, art. 5; 6; 52.

${ }^{27}$ Annex III to the Regulation Proposal.

${ }^{28}$ The Regulation Proposal, art. 56 through 59 and art. 71.
} 


\section{PRÁVNE ROZPRAVY ON-SCREEN III. - Sekcia verejného práva}

online vedecká konferencia - 7. máj 2021

ecosystems - the ecosystem of excellence and the ecosystem of trust. And while the latter is all about the protection of the consumer's rights, the former is called upon to ensure that businesses get a coherently regulated cooperative and competitive environment - the mix that is very efficient when it comes to the necessity to boost creativity and productivity of the developers of AI-driven solutions to remain on the edge of the technological revolution.

\section{ZOZNAM BIBLIOGRAFICKÝCH ODKAZOV}

BAUER, W. et all: A Definition of AI: Main Capabilities and Scientific Disciplines. In: Report/study by the High-Level Expert Group on Artificial Intelligence [online]. Brussels: European Commission, 2019 [cit. 2021-05-03], p. 1. Available at: https://digitalstrategy.ec.europa.eu/en/library/definition-artificial-intelligence-main-capabilities-andscientific-disciplines.

CHRISTENSEN, C.M. - RAYNOR, M.E. - McDONALD, R.: What is Disruptive Innovation? In: Harvard Business Review [online]. Brighton MA, 2015 [cit.2021-05-08], Available at: https://hbr.org/2015/12/what-is-disruptive-innovation;

Ethics guidelines for trustworthy AI [online]. Brussels: European Commission. High-Level Expert Group on Artificial Intelligence, 2020 [cit.2021-05-10], Available at: https://digitalstrategy.ec.europa.eu/en/library/ethics-guidelines-trustworthy-ai.

GIUFFRIDA, I. - LEDERER, F. - VERMEYS, N.: A Legal Perspective on the Trials and Tribunals of AI: How Artificial Intelligence, the Internet of Things, Smart Contracts, and Other Technologies Will Affect the Law. In: Case Western Reserve Law Review, 2018, Vol. 68, Iss. 3. ISSN 0008-7262, p. 752.

HUNT, E.: Tay, Microsoft's AI chatbot, gets a crash course in racism from Twitter. In: The Guardian 2016 [online]. [cit. 2021-05-05], Available at: https://www.theguardian.com/technology/2016/mar/24/tay-microsofts-ai-chatbot-gets-acrash-course-in-racism-from-twitter.

MAJID AL-RIFAIE, M. - BISHOP, M.: Weak vs. Strong Computational Creativity. In: Conference: AISB 2012: Computing and Philosophy [online]. Conference Paper, 2012 [cit.2021-05-04], p. 3. Available at: https://www.researchgate.net/publication/262223177_ Weak_vs_Strong_Computational_Creativity. 


\section{PRÁVNE ROZPRAVY ON-SCREEN III. - Sekcia verejného práva}

online vedecká konferencia-7. máj 2021

OSTHERR, K.: Artificial Intelligence and Medical Humanities. In: Journal of Medical Humanities, 2020. ISSN 1573-3645;

SCHUETT, J.: A Legal Definition of AI. In: ArXiv: 1909.01095v1 [online]. Frankfurt: 2019 [cit. 2021-05-02], p. 3. Available at: https://papers.ssrn.com/sol3/papers.cfm? abstract_id=3453632.

The Commission's Proposal for a Regulation 2021/0106 (COD) of the European Parliament and of the Council Laying Down Harmonized Rules on Artificial Intelligence and Amending Certain Union Legislative Acts.

VAN EECKE, P. et all: AI Outlook: Europe initiates AI regulation introducing the principle of trustworthy AI. In: Technology's Legal Edge. A global technology sector blog, DLA Piper [online]. 2020 [cit.2021-05-08], Available at: https://www.technologyslegaledge.com/2020/03/ ai-outlook-europe-initiates-ai-regulation-introducing-the-principle-of-trustworthy-ai/\#page=1. What is Artificial Intelligence and how it is Used? [online]. Brussels: European Parliament, 2020 [cit. 2021-05-03], Available at: https://www.europarl.europa.eu/news/en/headlines/ society/20200827STO85804/what-is-artificial-intelligence-and-how-is-it-used.

White Paper on Artificial Intelligence - a European approach on excellence and trust. In: White Paper [online]. Brussels: European Commission, 2020 [cit.2021-05-06]. Available at: https://ec.europa.eu/info/sites/default/files/commission-white-paper-artificial-intelligencefeb2020_en.pdf.

Obsah článku podlieha licencii Creative Commons Attribution 4.0 International Licence CC BY (Yevhen Shcherbyna). 